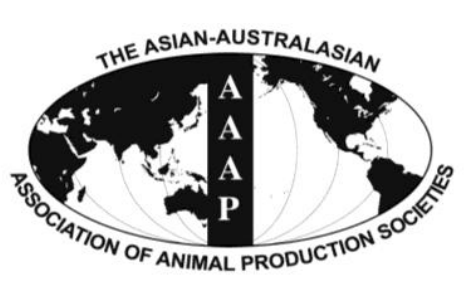

\begin{tabular}{c} 
Open Access \\
Asian Australas. J. Anim. Sci. \\
Vol. 27, No. 4 : 551-560 April 2014 \\
http://dx.doi.org/10.5713/ajas.2013.13555 \\
\hline www.ajas.info \\
pISSN 101 1-2367 elSSN 1976-5517
\end{tabular}

\title{
Carcass Characteristics and Meat Quality of Swamp Buffaloes (Bubalus bubalis) Fattened at Different Feeding Intensities
}

\author{
C. Lambertz ${ }^{1}$,*, P. Panprasert ${ }^{1}$, W. Holtz ${ }^{1}$, E. Moors ${ }^{1}$, S. Jaturasitha, M. Wicke ${ }^{1}$, and M. Gauly ${ }^{1}$ \\ Department of Animal Science, Faculty of Agriculture, Chiang Mai University, Chiang Mai 50200, Thailand
}

\begin{abstract}
Twenty-four male 1-year old swamp buffaloes (Bubalus bubalis) were randomly allocated to 4 groups. One group grazed on guinea grass (GG) and another on guinea grass and the legume Stylosanthes guianensis (GL). The other two groups were kept in pens and fed freshly cut guinea grass and concentrate at an amount of $1.5 \%$ (GC1.5) and 2.0\% (GC2.0) of body weight, respectively. The effect of the different feeding intensities on carcass characteristics and meat quality were assessed. The mean body weight at slaughter was $398( \pm 16) \mathrm{kg}$. Average daily gain was higher in concentrate-supplemented groups (570 and 540 g/d in GC1.5 and GC2.0, respectively) when compared to GG $(316 \mathrm{~g} / \mathrm{d})$ and GL $(354 \mathrm{~g} / \mathrm{d})(\mathrm{p}<0.01)$. Likewise, the warm carcass weight was higher in GC1.5 and GC2.0 compared to GG and GL. Dressing percentage was $48.1 \%$ and $49.5 \%$ in GC1.5 and GC2.0 in comparison to $42.9 \%$ and $44.8 \%$ observed in GG and GL, respectively. Meat of Longissimus throracis from GC1.5 and GC2.0 was redder in color ( $<<0.01$ ), while water holding capacity (drip and thawing loss) was improved in pasture-fed groups ( $\mathrm{p}<0.05)$. Protein and fat content of Longissimus thoracis was higher in animals supplemented with concentrate $(\mathrm{p}<0.01)$, as was cholesterol content $(\mathrm{p}<0.05)$, whereas PUFA:SFA ratio was higher and $n-6 / n-3$ ratio lower $(p<0.01)$ in pasture-fed buffaloes. Results of the present study showed that the supplementation of pasture with concentrate enhances the growth and carcass characteristics of swamp buffaloes expressed in superior dressing percentage, better muscling, and redder meat with a higher content of protein and fat, whereas animals grazing only on pasture had a more favorable fatty acid profile and water holding capacity. In conclusion, the supplementation of concentrate at a rate of about $1.5 \%$ of body weight is recommended to improve the performance and carcass quality of buffaloes. (Key Words: Swamp Buffaloes, Guinea Grass, Stylosanthes guianensis, Meat Quality, Carcass Composition, Fatty Acids)
\end{abstract}

\section{INTRODUCTION}

The buffalo (Bubalus bubalis) is an important contributor of milk, meat, power, fuel, and leather in many less industrialized countries. The world buffalo population is estimated at 166.4 million spread over 129 countries around the world (FAO, 2000, 2001; FAOSTAT, 2006). Of these, 161.4 million are found in Asia (97.2\%), 3.6 million in Africa (2.2\%), 1.4 million in South America, and 0.3 million in Europe $(0.2 \%)$ (Ingawale and Dhoble, 2004). In

\footnotetext{
* Corresponding Author: C. Lambertz. Tel: +49-551-39-5613, Fax: +49-551-39-5587, E-mail: clamber2@gwdg.de

1 Department of Animal Sciences, Georg-August-University Göttingen, Albrecht-Thaer-Weg 3, 37075 Göttingen, Germany. Submitted Sept. 6, 2013; Accepted Nov. 25, 2013; Revised Dec. 9, 2013
}

Thailand, swamp buffaloes are traditionally kept as draft animals, for providing manure for use as fuel and fertilizer, and for meat production (Nanda and Nakao, 2003). Buffaloes are particularly capable of converting poor quality fibrous feeds into milk and meat (FAO, 2000). Traditionally, buffalo meat originated from retired draft animals generally ageing more than 10 years (Nanda and Nakao, 2003) and, therefore, is in public perception tougher and of lower quality than beef. However, if slaughtered at similar body weights than cattle, the carcass composition and quality of buffalo and cattle meat are comparable (Irurueta et al., 2008; Kandeepan et al., 2009).

The fatty acid composition of buffalo fat influences the nutritional value of the meat and affects various aspects of meat quality, including flavor and shelf life. For health issues an improvement in the polyunsaturated:saturated

Copyright @ 2014 by Asian-Australasian Journal of Animal Sciences This is an open-access article distributed under the terms of the Creative Commons Attribution Non-Commercial License (http://creativecommons.org/licenses/by-nc/3.0/), which permits unrestricted non-commercial use, distribution, and reproduction in any medium, provided the original work is properly cited. 
fatty acid ratio (PUFA:SFA) in favor of the former fatty acids is desired (Demirel et al., 2006). Previous studies suggested that the fatty acid composition of ruminant meat might be influenced by the fatty acid composition of the feed, though only protected lipids that pass through the rumen without hydrogenation have an influence on the fatty acid composition of the meat (Enser et al., 1998; Demirel et al., 2006). It has been demonstrated that forage legumes may modify the fatty acid profile of lipids contained in meat, resulting in an increase of desired n-3 fatty acids and leading to an advantage of beef from pasture-fed animals over beef from animals fed a high-concentrate ration (Scollan et al., 2006). However, only few data are available on the effect of legumes as forage (Jaturasitha et al., 2009) and there is a general lack in comparative studies concerning tropical forages.

Therefore, the effect of the feeding system on carcass and meat quality of young male swamp buffaloes was addressed with the intention to establish suitable ways of fattening buffaloes for producing high quality meat.

\section{MATERIALS AND METHODS}

\section{Animals and diets}

Twenty-four male buffaloes with a mean body weight of $202 \pm 10 \mathrm{~kg}$ obtained from the Mahasarakham Animal Nutrition and Development Station, Department of Livestock Development (DLD), Mahasarakham, Thailand, were weaned at an age of 1 year. They were randomly divided into 4 groups of 6 animals each. Animals of 1 group were grazed on a pasture of guinea grass (Panicum maxima; cultivar Purple guinea) (GG), those of group GL on guinea grass plus a legume (Stylosanthes guianensis). These two different grass-fed treatments were chosen, because pastures of guinea grass are widely found in buffalo production under Southeast Asian environmental conditions. The legume Stylosanthes guianensis provides the possibility to improve these pastures. The other 2 groups were kept in individual pens equipped with feeders and were provided with either $1.5 \%$ (GC1.5) or $2.0 \%$ (GC2.0) of their respective body weight of concentrate per day, in addition to freshly cut guinea grass provided ad libitum throughout the finishing period. Pastures were divided into 4 paddocks of $4,800 \mathrm{~m}^{2}$ each and were used in rotational grazing. Before a paddock was stocked, samples of grass and legume were cut $3 \mathrm{~cm}$ above the ground. Grass, legumes, and concentrates were analyzed by the methods of AOAC (1995) to determine dry matter content, total ash, crude protein (Kjeldahl; $6.25 \times \mathrm{N}$ ), and ether extract. Dietary fiber analyses were conducted according to van Soest et al. (1991). Feed composition is presented in Table 1. All buffaloes had free access to water, salt, and mineral blocks. Animal performance was calculated on the basis of live
Table 1. Chemical composition and fatty acid profile of concentrate, grass (Panicum maxima), and legume (Stylosanthes guianensis) provided

\begin{tabular}{lccc}
\hline Composition $^{1}$ & Concentrate & Grass & Legume \\
\hline Dry matter (\%) & 86.7 & 92.7 & 92.9 \\
Crude protein (\%) & 11.5 & 7.7 & 11.6 \\
Ether extract (\%) & 3.1 & 2.1 & 2.5 \\
Acid detergent fiber (\%) & 3.6 & 32.4 & 27.9 \\
Ash (\%) & 5.1 & 9.8 & 8.5 \\
Fatty acids (mg/100 g) & & & \\
$\quad$ SFA & 59.1 & 29.4 & 30.6 \\
MUFA & 27.5 & 5.0 & 5.2 \\
PUFA & 13.3 & 65.7 & 64.2 \\
PUFA:SFA ratio & 0.2 & 2.2 & 2.1 \\
\hline
\end{tabular}

${ }^{1}$ SFA $=$ Saturated fatty acids, MUFA $=$ Monounsaturated fatty acids, PUFA $=$ Polyunsaturated fatty acids .

weight that was determined at monthly intervals.

\section{Slaughter procedures}

Animals were slaughtered at an average body weight of $385 \pm 10 \mathrm{~kg}(\mathrm{SD})$. All experimental procedures were carried out following the animal welfare standards of the Department of Livestock Development, Ministry of Agriculture and Cooperative, Royal Thai Government. Buffaloes were fasted for $12 \mathrm{~h}$ before being trucked to Tak slaughterhouse at the Livestock Research and Development Center, Tak province, Thailand, following the procedures outlined by Jaturasitha (2007). The average duration of transport was $12 \mathrm{~h}$. After a resting period of $24 \mathrm{~h}$, animals were slaughtered by exsanguination after stunning by captive bolt. Immediately after slaughter and chilling at $4^{\circ} \mathrm{C}$ for $24 \mathrm{~h}$ carcass weight and length were determined. The right half of the carcass was weighed and dressed into retail cuts according to Meat and Livestock Commission standards (MLC; Church and Wood, 1991); the left half was dissected into bone, lean meat, trim meat, tendon, and fat (Jaturasitha, 2007). The loin eye area was determined by tracing the Longissimus thoracis (LT) muscle cut between the 12th and 13th rib on transparent paper. The weights of the various tissues were recorded and expressed as percentage of carcass weight.

\section{Meat evaluation}

The $\mathrm{pH}$ of the LT was determined (pH meter, Model 191, Knick, Berlin, Germany) at 45 min and 24 h post mortem by inserting the electrode about $5 \mathrm{~cm}$ into the LT between the 12th and 13th rib. The $\mathrm{pH}$ meter was calibrated in 4.0 and 7.0 buffer solutions after each carcass. Meat color was measured on $2.5 \mathrm{~cm}$ slices of LT after being bloomed for $1 \mathrm{~h}$ at $4^{\circ} \mathrm{C}$ using a Minolta CR-300 colorimeter (Minolta Camera Co. Ltd, Osaka, Japan), which was calibrated against a white calibration plate. The instrument reads 
lightness $\left(\mathrm{L}^{*}\right)$, redness $\left(\mathrm{a}^{*}\right)$, and yellowness $\left(\mathrm{b}^{*}\right)$ of the meat. To assess thawing and cooking loss, a $2.5 \mathrm{~cm}$ slice of LT vacuum-sealed in a polyethylene bag was frozen at $-20^{\circ} \mathrm{C}$. Samples were thawed at $4^{\circ} \mathrm{C}$ for $24 \mathrm{~h}$ and placed in a water bath at $80^{\circ} \mathrm{C}$ until an internal temperature of $70^{\circ} \mathrm{C}$ had been reached. Thereafter, a thermocouple (Consort T851, Cohasset, MA, USA) was inserted into the meat. For determining grilling loss, $2.5 \mathrm{~cm}$ slices of LT were grilled in a convection oven (model 720, Mara, Taipei, Taiwan) at $150^{\circ} \mathrm{C}$ until reaching an internal temperature of $70^{\circ} \mathrm{C}$. Drip loss was determined according to Honikel (1987). Water holding capacity was assessed via the substance losses that occurred during the different procedures. In water bathcooked samples, shear force was measured using a hollowcore punch, whereas 6 cylindrical pieces of $1.27 \mathrm{~cm}$ diameter were punched out parallel to the muscle fibers. Shear force was measured with the aid of a material testing machine (Warner-Bratzler shear, model 5565, Instron Ltd., Buckinghamshire, UK). A crosshead speed of $200 \mathrm{~mm} / \mathrm{min}$ and a $5 \mathrm{kN}$ load cell calibrated to read over a range of 0 to $100 \mathrm{~N}$ were applied.

Susceptibility of the lipids to oxidation was assessed by the 2-thiobarbituric acid method (TBARS) in ground meat stored for 0,3 , and 6 days at $4^{\circ} \mathrm{C}$ (Rossell, 1994). The TBARS value was obtained by multiplying the absorbance read by a factor of 7.8. Results were given as concentrations of malondialdehyde in meat. LT samples were minced and oven-dried for $18 \mathrm{~h}$ at $104^{\circ} \mathrm{C}$ before fat was extracted with the aid of diethyl ether according to the AOAC (1995). Cholesterol was analyzed according to Jung et al. (1975). Soluble, insoluble, and total collagen was determined according to Hill (1966) and AOAC (2000). Soluble collagen was calculated as $7.52 \times$ hydroxyproline and insoluble collagen as $7.25 \times$ hydroxyproline found in the supernatant of the preparation.

Fatty acids in LT muscle, forage, and concentrate were determined after fat extraction by a mixture of chloroform and methanol according to the method of Folch, Lees and Stanley (1957). Samples were prepared for fatty acid methyl ester (FAME) determination according to Morrison and Smith (1964). Chromatography of fatty acids was performed with the aid of a gas chromatograph (Shimadzu; Model GC-14B, Kyoto, Japan) equipped with a $0.25 \mathrm{~mm} \times$ $30 \mathrm{~m} \times 0.25 \mu \mathrm{m}$ wall-coated wax capillary column. For heating the samples the following program was used: from $50^{\circ} \mathrm{C}$ to $220^{\circ} \mathrm{C}$ the temperature increased at a rate of $10^{\circ} \mathrm{C} / \mathrm{min}$, then remained at $220^{\circ} \mathrm{C}$ for $35 \mathrm{~min}$, increased further to $230^{\circ} \mathrm{C}$ at a rate of $5^{\circ} \mathrm{C} / \mathrm{min}$, and remained at $230^{\circ} \mathrm{C}$ for another $20 \mathrm{~min}$. Helium at a flow rate of 1 $\mathrm{mL} / \mathrm{min}$ was used as carrier gas. Injector and detector temperature were $250^{\circ} \mathrm{C}$. Chromatograms were processed using the Millenium 2010 Chromatography Manager (Millipore Corp., Milford, Massachusetts, USA).

\section{Statistical analysis}

The experiment consisted of a completely randomized design with 4 treatment groups. Data were analyzed by 1way-ANOVA using the software SAS (2008). Significant treatment effects (ANOVA) were subjected to multiple comparisons using Tukey's test with a significance level of $\mathrm{p}<0.05$. The results were presented as means and pooled standard errors of the means.

\section{RESULTS AND DISCUSSION}

\section{Growth performance}

As evident from Table 2, the feeding system had a significant effect on the average daily weight gain. At 570 $\mathrm{g} /$ day, animals of GC1.5 had the highest gains, closely followed by GC2.0 with $540 \mathrm{~g} / \mathrm{d}(\mathrm{p}<0.01)$. Both groups were superior to the 2 pasture-fed groups GG and GL. However, it has to be considered here that the body weight

Table 2. Growth performance and carcass characteristics of male buffaloes grazed on guinea grass (GG), on guinea grass and the legume Stylosanthes guianensis (GL), and fed with guinea grass and concentrate at an amount of 1.5\% (GC1.5) and 2.0\% (GC2.0) of body weight, respectively $(\mathrm{N}=6)$

\begin{tabular}{|c|c|c|c|c|c|c|}
\hline \multirow{2}{*}{ Parameter } & \multicolumn{4}{|c|}{ Group } & \multirow{2}{*}{ PSE } & \multirow{2}{*}{ p-value } \\
\hline & GG & GGL & GGC1.5 & GGC2.0 & & \\
\hline Initial weight (kg) & 211.2 & 229.3 & 202.2 & 204.2 & 9.7 & 0.219 \\
\hline Final weight $(\mathrm{kg})$ & 367.3 & 373.8 & 402.5 & 394.8 & 20.3 & 0.574 \\
\hline Fattening period (d) & $494.3^{\mathrm{a}}$ & $414.5^{\mathrm{ab}}$ & $349.5^{\mathrm{b}}$ & $349.5^{\mathrm{b}}$ & 36.5 & 0.033 \\
\hline Average daily gain $(\mathrm{g} / \mathrm{d})$ & $316.2^{\mathrm{c}}$ & $354.3^{\mathrm{c}}$ & $569.8^{\mathrm{a}}$ & $539.7^{\mathrm{b}}$ & 29.9 & 0.001 \\
\hline \multicolumn{7}{|l|}{ Carcass characteristics } \\
\hline Warm carcass (kg) & $161.0^{\mathrm{b}}$ & $171.2^{\mathrm{ab}}$ & $204.7^{\mathrm{a}}$ & $204.2^{\mathrm{a}}$ & 1.7 & 0.003 \\
\hline Chilled carcass (kg) & $157.2^{\mathrm{c}}$ & $166.8^{\mathrm{bc}}$ & $203.1^{\mathrm{a}}$ & $187.8^{\mathrm{ab}}$ & 18.1 & 0.001 \\
\hline Dressing (\%) & $42.9^{\mathrm{b}}$ & $44.8^{\mathrm{ab}}$ & $49.5^{\mathrm{a}}$ & $48.1^{\mathrm{ab}}$ & 3.3 & 0.012 \\
\hline Carcass length $(\mathrm{cm})$ & 142.1 & 143.2 & 144.5 & 143.1 & 5.8 & 0.909 \\
\hline Loin eye area $\left(\mathrm{cm}^{2}\right)$ & $39.8^{\mathrm{b}}$ & $43.8^{\mathrm{ab}}$ & $49.1^{\mathrm{a}}$ & $47.8^{\mathrm{ab}}$ & 5.2 & 0.022 \\
\hline
\end{tabular}

$\overline{\mathrm{a}, \mathrm{b}, \mathrm{c}}$ Within rows, means with different superscripts differ $(\mathrm{p}<0.05$, Tukey-test). 
at slaughter was higher in concentrate- compared to pasturefed animals. Nevertheless, Muir et al. (1998) reported differences at similar ranges between concentrate- and pasture-fed Aberdeen Angus steers. In detail, those animals being finished with concentrate-based diets reached weight gains of $1,030 \mathrm{~g} / \mathrm{d}$ as compared to 600 to $700 \mathrm{~g} / \mathrm{d}$ when finished on grass. Similar results were also described by Myers et al. (1999). Buffaloes are reported to utilize nutrients more efficiently than cattle when fed poor quality rations containing high levels of cellulose. Their rumen microbes were found to have a greater fibrolytic activity than those of cattle (Wanapat et al., 2000; Lapitan et al., 2008). However, Spanghero et al. (2004) found that male buffaloes (Italian Mediterranean) grew more slowly than bovine bulls (Italian Simmental) (930 vs 1,040 g/d, p = 0.07) under intensive feeding conditions. Under the environmental conditions of Southeast Asia, pastures consisting of tropical grasses are typically characterized by a low digestibility and crude protein contents. Therefore, the combination of grasses with forage legumes is a way to improve the quality of pastures (Hess et al., 2003). In the study of Jaturasitha et al. (2009), cattle were either fattened on pasture consisting of guinea grass only or on pasture consisting of guinea grass in combination with the forage legume Stylosanthes guianensis. As a main finding, meat of the grass-legume-fed animals had a higher intramuscular fat content. Other studies demonstrated that forage legumes may modify the fatty acid profile of lipids contained in meat, resulting in an increase of desired n-3 fatty acids and leading to an advantage of beef from pasture-fed animals over beef from animals fed a high-concentrate ration (Scollan et al., 2006).

\section{Carcass yield and quality}

As indicated in Table 2, hot and chilled carcass weights were significantly higher in the groups receiving concentrate $(\mathrm{p}<0.01)$, whereas carcass length was unaffected by the feeding intensity. Dressing percentage was highest in GC1.5 as was loin eye area $(\mathrm{p}<0.05)$. For both parameters the lowest values were recorded in GG. The results of cutting according to the MLC pattern are shown in Table 2. Concentrate feeding significantly increased the relative weights of brisket and short loin $(\mathrm{p}<0.05)$; no effect on the remaining cuts was observed. Boles et al. (2004) reported higher USDA quality grades for carcasses from steers that had been fed diets based on Harrington barley variety, than carcasses from concentrate-finished cattle. The latter had reached an advanced degree of finishing with more fat covering and rib eye area than pasture-finished cattle ( $\mathrm{p}<0.05)$. According to Sañudo et al. (1997), higher carcass weight implies more muscling and fat deposit, which means the carcass and all of its components have greater dimensions. Consequently, at higher carcass weight relatively more fat and less bone is expected, whereas the proportion of muscle tissue will be unchanged.

The result of the dissection into various tissues showed significant differences $(p<0.01)$ between pasture-reared and concentrate-supplemented bulls only with regard to the proportion of bone and fat; bone being higher in pasturereared and fat higher in concentrate-supplemented bulls, though this may be partly due to the fact that concentratefed animals were heavier than pasture-fed ones (Table 3). Tiwari et al. (2001) found higher dressing percentages and yields of lean meat when buffaloes were fed a high energy diet compared to those fed a low concentrate diet. Anjaneyulu et al. (1985) did not find an influence of different dietary protein levels on carcass composition of male buffalo calves. Still, little information is available on the effect of the feeding system on the proportion of various tissues in buffaloes.

\section{Meat quality}

As shown in Table 4, the $\mathrm{pH}$ recorded $45 \mathrm{~min}$ and $24 \mathrm{~h}$ after slaughter was not affected by the feeding system. As an important post-slaughter factor the $\mathrm{pH}$ plays an important role for the meat quality. Post mortem glycolysis in muscles results in a decrease of the $\mathrm{pH}$ excerting a positive effect on the tenderness of meat (Ziauddin et al., 1994). Stressful conditions prior to slaughter cause a depletion of muscle glycogen reserves, thus reducing the potential for post mortem $\mathrm{pH}$ decline (Forrest et al., 1975; Muir et al., 1998). Though in agreement with other studies, the $24 \mathrm{~h} \mathrm{pH}$ of 5.8 to 6.0 found in the present study is high and might be lower if the pre-slaughter handling would be improved, particularly if the transport duration would have been reduced.

Meat color is an important criterion by which many consumers evaluate meat quality and acceptability (Sami et al., 2006; Serrano et al., 2007). In the present study the feeding system had no effect on lightness ( $\mathrm{L}^{*}$ ) of buffalo meat, whereas meat from concentrate-supplemented buffaloes was redder in color than of pasture-fed animals $(\mathrm{p}<0.01)$. This contradicts studies in cattle by Bennet et al. (1995) and Nuernberg et al. (2005) who reported darker muscle color in forage- than in concentrate-fed animals. Varnam and Sutherland (1995) hypothesized that, due to higher physical activity, animals grazed on pasture have higher concentrations of myoglobin than animals kept indoors and fed concentrates. Vestergaard et al. (2000) described a higher proportion of oxidative fibers and darker meat in pasture-fed young bulls as compared to grain-fed animals. Similarly, Raes et al. (2003) reported paler meat from intensively fed Belgian Blue cattle than from cattle raised on pasture. The redder color found in the concentrate-supplemented animals can be mainly explained by the relatively low amount of concentrate fed in addition 
Table 3. Carcass composition of male buffaloes grazed on guinea grass (GG), on guinea grass and the legume Stylosanthes guianensis (GL), and fed with guinea grass and concentrate at an amount of $1.5 \%$ (GC1.5) and 2.0\% (GC2.0) of body weight, respectively ( $\mathrm{N}=6)$

\begin{tabular}{|c|c|c|c|c|c|c|}
\hline \multirow{2}{*}{ Parameter } & \multicolumn{4}{|c|}{ Group } & \multirow{2}{*}{ PSE } & \multirow{2}{*}{ p-value } \\
\hline & GG & GL & GC1.5 & GC2.0 & & \\
\hline \multicolumn{7}{|c|}{ Sandard MLC cutting (\% of chilled carcass) } \\
\hline \multicolumn{7}{|l|}{ Forequarter } \\
\hline Chuck & 26.4 & 26.6 & 24.9 & 27.3 & 1.5 & 0.089 \\
\hline Fore shank & 7.2 & 7.4 & 7.5 & 7.5 & 0.4 & 0.979 \\
\hline Brisket & $4.9^{\mathrm{ab}}$ & $4.6^{\mathrm{b}}$ & $5.6^{\mathrm{a}}$ & $5.9^{\mathrm{a}}$ & 0.3 & 0.001 \\
\hline Rib & 8.9 & 7.9 & 9.4 & 10.3 & 1.0 & 0.352 \\
\hline Plate & 7.7 & 7.9 & 8.9 & 9.1 & 0.6 & 0.275 \\
\hline Fat & 3.0 & 3.4 & 3.4 & 3.6 & 0.2 & 0.098 \\
\hline \multicolumn{7}{|l|}{ Hind quarter } \\
\hline Flank & 3.9 & 4.1 & 4.3 & 4.2 & 0.3 & 0.841 \\
\hline Short loin & $6.7^{\mathrm{b}}$ & $7.1^{\mathrm{b}}$ & $8.9^{\mathrm{ab}}$ & $10.3^{\mathrm{a}}$ & 0.8 & 0.013 \\
\hline Sirloin & 9.7 & 10.2 & 8.7 & 9.5 & 0.4 & 0.129 \\
\hline Round & 25.3 & 25.2 & 24.5 & 24.1 & 0.4 & 0.110 \\
\hline \multicolumn{7}{|c|}{ Proportion of various tissues ( $\%$ of chilled carcass) } \\
\hline Lean meat & 59.9 & 57.7 & 58.9 & 61.3 & 1.1 & 0.133 \\
\hline Bone & $21.9^{\mathrm{a}}$ & $20.8^{\mathrm{ab}}$ & $18.7^{\mathrm{b}}$ & $18.4^{\mathrm{b}}$ & 0.7 & 0.008 \\
\hline Fat & $8.1^{\mathrm{b}}$ & $8.8^{\mathrm{ab}}$ & $11.8^{\mathrm{ab}}$ & $12.7^{\mathrm{a}}$ & 1.0 & 0.008 \\
\hline Trim meat & 0.5 & 0.5 & 1.1 & 0.7 & 0.2 & 0.203 \\
\hline Tendon & 3.1 & 2.9 & 2.6 & 3.5 & 0.3 & 0.384 \\
\hline
\end{tabular}

$\overline{\mathrm{a}, \mathrm{b}, \mathrm{c}}$ Within rows, means with different superscripts differ $(\mathrm{p}<0.05$, Tukey-test).

to the freshly-cut guinea grass. The intensive fattening of cattle mentioned in the studies above is based on the concentrate supplementation of diets that have a much higher nutrient content than the diets relying only on guinea grass studied here.

Water holding capacity of the LT muscle was higher in concentrate-supplemented than in pasture-fed buffaloes $(\mathrm{p}<0.05)$, resulting in lower drip and thawing losses. With regard to grilling and boiling loss, no significant differences among groups were observed $(\mathrm{p}<0.05)$. In meat subjected to heating, coagulation of proteins and thermal shrinkage takes place, resulting in the release of meat juice. Cooking losses are dependent on the type of meat, trim time, temperature, $\mathrm{pH}$, sarcomere length, and the method of cooking (Lawrie,

Table 4. Physical characteristics of Longissimus thoracis muscle of male buffaloes grazed on guinea grass (GG), on guinea grass and the legume Stylosanthes guianensis (GL), and fed with guinea grass and concentrate at an amount of 1.5\% (GC1.5) and 2.0\% (GC2.0) of body weight, respectively $(\mathrm{N}=6)$

\begin{tabular}{|c|c|c|c|c|c|c|}
\hline \multirow{2}{*}{ Parameter } & \multicolumn{4}{|c|}{ Group } & \multirow{2}{*}{ PSE } & \multirow{2}{*}{ p-value } \\
\hline & GG & GL & GC1.5 & GC2.0 & & \\
\hline \multicolumn{7}{|l|}{ pH-value } \\
\hline $45 \mathrm{~min}$ & 6.64 & 6.58 & 6.62 & 6.49 & 0.09 & 0.700 \\
\hline $24 \mathrm{~h}$ & 5.83 & 5.77 & 5.97 & 5.88 & 0.10 & 0.594 \\
\hline \multicolumn{7}{|l|}{ Color } \\
\hline Lightness (L*) & 35.5 & 36.6 & 35.7 & 36.6 & 1.94 & 0.740 \\
\hline Redness (a*) & $14.8^{\mathrm{bc}}$ & $13.8^{\mathrm{c}}$ & $17.1^{\mathrm{a}}$ & $16.1^{\mathrm{ab}}$ & 0.75 & 0.001 \\
\hline Yellowness (b*) & $9.5^{\mathrm{a}}$ & $9.9^{\mathrm{a}}$ & $7.9^{\mathrm{ab}}$ & $7.4^{\mathrm{b}}$ & 1.29 & 0.005 \\
\hline \multicolumn{7}{|l|}{ Water holding capacity } \\
\hline Drip loss (\%) & $6.0^{\mathrm{ab}}$ & $5.7^{\mathrm{b}}$ & $9.6^{\mathrm{a}}$ & $9.2^{\mathrm{ab}}$ & 0.98 & 0.013 \\
\hline Thawing loss (\%) & $6.8^{\mathrm{b}}$ & $6.1^{\mathrm{b}}$ & $13.2^{\mathrm{a}}$ & $10.9^{\mathrm{ab}}$ & 1.34 & 0.003 \\
\hline Grilling loss (\%) & 31.2 & 32.4 & 33.8 & 38.6 & 2.82 & 0.299 \\
\hline Boiling loss $(\%)$ & 31.4 & 29.8 & 32.9 & 33.5 & 2.02 & 0.580 \\
\hline \multicolumn{7}{|l|}{ Shear force } \\
\hline Force $(\mathrm{N})$ & 40.3 & 44.9 & 39.2 & 39.8 & 6.41 & 0.491 \\
\hline Energy $(\mathrm{mJ})$ & 155.8 & 170.6 & 133.5 & 140.8 & 24.50 & 0.084 \\
\hline
\end{tabular}

$\overline{\mathrm{a}, \mathrm{b}, \mathrm{c}}$ Within rows, means with different superscripts differ $(\mathrm{p}<0.05$, Tukey-test). 
Table 5. Chemical characteristics of Longissimus thoracis muscle of male buffaloes grazed on guinea grass (GG), on guinea grass and the legume Stylosanthes guianensis (GL), and fed with guinea grass and concentrate at an amount of 1.5\% (GC1.5) and 2.0\% (GC2.0) of body weight, respectively $(\mathrm{N}=6)$

\begin{tabular}{|c|c|c|c|c|c|c|}
\hline \multirow{2}{*}{ Parameter } & \multicolumn{4}{|c|}{ Group } & \multirow{2}{*}{ PSE } & \multirow{2}{*}{ p-value } \\
\hline & GG & GL & GC1.5 & GC2.0 & & \\
\hline \multicolumn{7}{|l|}{ Chemical composition (\%) } \\
\hline Water & $75.73^{\mathrm{a}}$ & $74.78^{\mathrm{a}}$ & $72.34^{\mathrm{b}}$ & $73.04^{\mathrm{b}}$ & 0.46 & 0.001 \\
\hline Protein & $22.36^{\mathrm{b}}$ & $22.99^{\mathrm{b}}$ & $24.81^{\mathrm{a}}$ & $24.83^{\mathrm{a}}$ & 0.32 & 0.001 \\
\hline Fat & $1.08^{\mathrm{c}}$ & $1.47^{\mathrm{c}}$ & $4.02^{\mathrm{a}}$ & $2.97^{\mathrm{b}}$ & 0.38 & 0.001 \\
\hline Cholesterol (mg/100 g) & $45.36^{\mathrm{b}}$ & $46.20^{\mathrm{b}}$ & $59.22^{\mathrm{a}}$ & $53.47^{\mathrm{a}}$ & 4.05 & 0.005 \\
\hline \multicolumn{7}{|c|}{ Collagen content (g/100 g meat) } \\
\hline Total & $1.32^{\mathrm{b}}$ & $1.18^{\mathrm{b}}$ & $1.56^{\mathrm{a}}$ & $1.64^{\mathrm{a}}$ & 0.08 & 0.001 \\
\hline Soluble & $0.29^{\mathrm{bc}}$ & $0.28^{\mathrm{c}}$ & $0.32^{\mathrm{a}}$ & $0.30^{\mathrm{ab}}$ & 0.01 & 0.001 \\
\hline Insoluble & 1.03 & 0.89 & 1.09 & 1.10 & 0.09 & 0.123 \\
\hline \multicolumn{7}{|c|}{ TBARS (mg malondialdehyde/kg meat) } \\
\hline Day 0 & $0.09^{\mathrm{ab}}$ & $0.11^{\mathrm{a}}$ & $0.07^{\mathrm{c}}$ & $0.07^{\mathrm{bc}}$ & 0.01 & 0.001 \\
\hline Day 3 & $0.11^{\mathrm{a}}$ & $0.10^{\mathrm{a}}$ & $0.08^{\mathrm{b}}$ & $0.08^{\mathrm{b}}$ & 0.01 & 0.001 \\
\hline Day 6 & 0.13 & 0.14 & 0.11 & 0.16 & 0.03 & 0.349 \\
\hline
\end{tabular}

$\overline{a, b, c}$ Within rows, means with different superscripts differ $(\mathrm{p}<0.05$, Tukey-test).

1998; Jaturasitha, 2007). Post-thaw phenomena are linked to the degree of damage to muscle fibers (Mortensen et al., 2006) and the distribution of water in different histological compartments (Huff-Lonergan and Lonergan, 2005). Whereas the thawing losses recorded here differed from those reported by Spanghero et al. (2004), they agreed with findings by Ferrara and Infascelli (2004). Lower thawing loss and better $\mathrm{pH}$ stability of meat suggest less freezing damage. French et al. (2000) and Marino et al. (2006) found no effect of the energy content of the diet on the chemical composition of meat.

Shear force (Table 4) and collagen content (Table 5) of the LT muscle are indicators of tenderness, which is one of the most important components of meat quality. As already mentioned for the cooking losses, shear values are influenced by the type of meat, trim time, temperature, $\mathrm{pH}$, sarcomere length, and the method of cooking (Lawrie, 1998; Jaturasitha, 2007). Furthermore, it is related to the rate of post mortem degradation of the myofibrils, linked to biochemical proteolysis as well as the amount of collagen present around, respectively between, muscle fibers (Maltin et al., 2001). French et al. (2001) found no difference in meat quality with respect to color, shear force, or sensory attributes between cattle finished on grass alone, on concentrates alone, or on various combinations. In the present study the feeding regime had no effect on the tenderness of meat, too. Total and soluble collagen content in meat from concentrate-supplemented buffaloes was significantly higher, whereas the content of insoluble collagen did not differ (Table 5), confirming findings by Díaz et al. (2002). The expectation that this meat would be more tender, as also stated by Nuernberg et al. (2005), was confirmed by the lower shear force value, even though statistical differences between the 4 groups were not noted here. Wheeler et al. (2002) calculated correlation coefficients between tenderness rating and total collagen content in bovine LD muscle (raw steak) of $\mathrm{r}=-0.12$ indicating a low relationship between the evaluation of the tenderness in test panels and the collagen content. It has to be noted that bulls raised on pasture were more than 100 days older than concentrate-supplemented bulls. According to Jaturasitha et al. (2009) collagen content is mainly dependent on age and, therefore, the higher contents of collagen in concentrate-fed animals may be partly caused by the age difference towards the pasture-fed groups. Listrat et al. (1999) found no difference in the collagen content of the semitendinosus muscle of Salers bulls fed either grass silage or hay, yet collagen solubility was higher in hay-fed bulls. When comparing extensive and intensive diets in Simmental bulls, Sami et al. (2004) found that collagen content did not differ but collagen solubility was higher in intensively-fed animals.

The chemical composition including moisture, protein, and fat percentage is summarized in Table 5. In concentratefed groups, the moisture content of the meat was lower $(\mathrm{p}<0.01)$ and the protein and fat content higher $(\mathrm{p}<0.01)$ compared to the two pasture-fed groups. The differences in chemical composition might be partly due to the higher carcass weight of the concentrate-fed animals. According to Ziauddin et al. (1994), a higher water and lower protein and fat content are indicators of animals that are either aged or not fed appropriately. The low intramuscular fat content reflects poor marbling, typical for buffalo carcasses. In steers of the Rubia Gallega breed, Varela et al. (2004) found that pasture feeding did not affect the intramuscular fat content when compared to a maize silage-concentrate diet, 
but no information on the slaughter weight are available. The LT muscle of the concentrate-supplemented groups had a significantly higher cholesterol content than the other groups $(\mathrm{p}<0.01)$.

Oxidative rancidity of lipids is a serious problem in storing meat and meat products. The TBARS value is the most common parameter to measure this. As shown in Table 5 , the TBARS value was increased after 3 days of storage $(\mathrm{p}<0.01)$, but later on differences evened out. Yang et al. (2002) found that it took 7 days for the TBARS value to increase significantly, except for a group fed grain. According to Nuernberg et al. (2005) and Dannenberger et al. (2006), grass feeding may improve meat stability, maintaining color and extending shelf life. Studies in cattle indicate that adipose tissue from pasture-fed animals has higher concentrations of $n-3$ PUFA than in animals fed concentrates. Increasing n-3 PUFA content increases the susceptibility to lipid oxidation (Realini et al., 2004). In cattle it has been shown that this is related to the naturally occurring high content of $\alpha$-tocopherol (Vitamin E) in grass. Vitamin $\mathrm{E}$ is an antioxidant helping to stabilize fat and color pigments in stored meat. Its presence in fresh grass may lead to saturation of $\alpha$-tocopherol in muscle tissue (Dannenberger et al., 2006).

\section{Fatty acid composition}

The impact of diet on the concentration of various fatty acids in LT muscle is presented in Table 6. Composite samples from grass-fed animals contained more SFA and PUFA; concentrate-supplemented animals had a higher $n$ $6 / n-3$ ratio $(p<0.01)$. It was shown that cattle fed exclusively grass, had a much higher concentrations of $n-3$ PUFA (Enser et al., 1998; French et al., 2000) as well as total MUFA (Miller et al., 1967; Enser et al., 1998) than concentrate-fed animals which, in turn, had higher n-6 PUFA concentrations. In agreement, Jaturasitha et al. (2009) showed an elevated $n-6 / n-3$ ratio in native Thai cattle fed legumes together with grass. Mitchell et al. (1991) and Enser et al. (1998) reported that adipose tissues in pasteurized cattle had high concentrations of n-3 PUFA, whereas, in animals raised on concentrate-based diets, concentrations of n-6 PUFA were higher. Earlier studies in cattle suggests a lower n-6/n-3 PUFA ratio in pasture-fed than in concentrate-fed animals. Finally, the important nutritional value, the $n-6 / n-3$ ratio, was beneficially decreased to less than 5:1, hence achieving an important target with respect to human health (Dannenberger et al., 2005; Nuernberg et al., 2005; Alfaia et al., 2006).

Pasture feeding enhanced the concentration of the sum of CLA-isomers in the lipid tissue. In our investigation, meat from pasture-fed buffaloes had significantly higher (GG; p<0.01) percentages of CLA than meat from concentrate-supplemented buffaloes. It has been shown, that the intake of CLA increases the low density lipoprotein

Table 6. Fatty acid profiles of Longissimus thoracis muscle of male buffaloes grazed on guinea grass (GG), on guinea grass and the legume Stylosanthes guianensis (GL), and fed with guinea grass and concentrate at an amount of 1.5\% (GC1.5) and 2.0\% (GC2.0) of body weight, respectively $(\mathrm{N}=6)$

\begin{tabular}{|c|c|c|c|c|c|c|}
\hline \multirow{2}{*}{ Parameter $^{1}$} & \multicolumn{4}{|c|}{ Group } & \multirow{2}{*}{ PSE } & \multirow{2}{*}{ p-value } \\
\hline & GG & GL & GC1.5 & GC2.0 & & \\
\hline \multicolumn{7}{|c|}{ Fatty acids (\% of total fatty acids) } \\
\hline $\mathrm{C} 14: 1$ & $0.30^{\mathrm{ab}}$ & $0.39^{\mathrm{a}}$ & $0.12^{\mathrm{c}}$ & $0.16^{\mathrm{bc}}$ & 0.05 & 0.001 \\
\hline C15:0 & $0.47^{\mathrm{a}}$ & $0.45^{\mathrm{a}}$ & $0.19^{\mathrm{b}}$ & $0.21^{\mathrm{b}}$ & 0.03 & 0.001 \\
\hline C16:1 & $2.56^{\mathrm{a}}$ & $2.13^{\mathrm{a}}$ & $1.50^{\mathrm{b}}$ & $1.57^{\mathrm{b}}$ & 0.20 & 0.001 \\
\hline $\mathrm{C} 17: 0$ & $1.04^{\mathrm{b}}$ & $1.19^{\mathrm{a}}$ & $1.14^{\mathrm{ab}}$ & $1.20^{\mathrm{a}}$ & 0.06 & 0.021 \\
\hline C18:1 & $37.20^{\mathrm{b}}$ & $37.20^{\mathrm{b}}$ & $45.40^{\mathrm{a}}$ & $45.50^{\mathrm{a}}$ & 0.97 & 0.001 \\
\hline $\mathrm{C} 18: 3 \mathrm{n}-3$ & $2.11^{\mathrm{a}}$ & $1.97^{\mathrm{a}}$ & $0.37^{\mathrm{b}}$ & $0.44^{\mathrm{b}}$ & 0.18 & 0.001 \\
\hline C18:1 n-9c & $0.69^{\mathrm{a}}$ & $0.57^{\mathrm{a}}$ & $0.19^{\mathrm{b}}$ & $0.20^{\mathrm{b}}$ & 0.07 & 0.001 \\
\hline $\mathrm{C} 20: 3 \mathrm{n}-6$ & $0.15^{\mathrm{ab}}$ & $0.22^{\mathrm{a}}$ & $0.12^{\mathrm{b}}$ & $0.20^{\mathrm{a}}$ & 0.03 & 0.003 \\
\hline C20:4 n-6 & $1.58^{\mathrm{ab}}$ & $2.10^{\mathrm{a}}$ & $0.96^{\mathrm{c}}$ & $1.25^{\mathrm{bc}}$ & 0.20 & 0.001 \\
\hline C20:5 n-3 & $1.16^{\mathrm{a}}$ & $1.19^{\mathrm{a}}$ & $0.25^{\mathrm{b}}$ & $0.34^{\mathrm{b}}$ & 0.11 & 0.001 \\
\hline SFA & $49.40^{\mathrm{a}}$ & $49.00^{\mathrm{a}}$ & $47.10^{\mathrm{ab}}$ & $45.60^{\mathrm{b}}$ & 1.08 & 0.003 \\
\hline MUFA & $40.70^{\mathrm{b}}$ & $40.40^{\mathrm{b}}$ & $47.50^{\mathrm{a}}$ & $47.90^{\mathrm{a}}$ & 1.04 & 0.001 \\
\hline PUFA & $9.89^{\mathrm{a}}$ & $10.60^{\mathrm{a}}$ & $5.36^{\mathrm{b}}$ & $6.55^{\mathrm{b}}$ & 0.83 & 0.001 \\
\hline Total n-6 & $5.61^{\mathrm{ab}}$ & $6.56^{\mathrm{a}}$ & $4.26^{\mathrm{b}}$ & $5.25^{\mathrm{ab}}$ & 0.71 & 0.020 \\
\hline Total n-3 & $3.60^{\mathrm{a}}$ & $3.45^{\mathrm{a}}$ & $0.90^{\mathrm{b}}$ & $1.10^{\mathrm{b}}$ & 0.19 & 0.001 \\
\hline \multicolumn{7}{|l|}{ Fatty acid ratio } \\
\hline PUFA:SFA & $0.20^{\mathrm{a}}$ & $0.22^{\mathrm{a}}$ & $0.12^{\mathrm{b}}$ & $0.15^{\mathrm{b}}$ & 0.02 & 0.001 \\
\hline$n-6 / n-3$ & $1.62^{\mathrm{b}}$ & $1.93^{\mathrm{b}}$ & $4.75^{\mathrm{a}}$ & $4.70^{\mathrm{a}}$ & 0.26 & 0.001 \\
\hline
\end{tabular}


cholesterol and decreases the high density lipoproteins (Valenzuela and Morgado, 1999). According to Realini et al. (2004), the best dietary sources of CLA are food products derived from grass-fed ruminants. In contrast to fatty acids, which are associated with coronary heart disease, many beneficial effects have been reported for CLA (Kritchevsky, 2000; Steen et al., 2003; Wood et al., 2008).

In summary, the concentrate-supplementation increased the performance and carcass quality of the animals. However, meat of animals grazed on pasture only was superior in water holding capacity and fatty acid profile. The study provides information that are useful to improve the production system of buffalo meat.

\section{IMPLICATIONS}

Results of the present study showed the effects of finishing buffalo bulls at different feeding intensities on growth and carcass quality. The supplementation of pasture with an amount of concentrate lead to an enhancement of growth and production of carcasses with superior dressing percentage, better muscling, and redder meat with a higher content of protein and fat. On the other hand, meat from buffalos reared solely on pasture had better water holding capacity (lower drip and thawing losses) and a more favorable fatty acid profile in terms of more CLA and n3PUFA. This is advantageous from a nutritional point of view. The study provides useful information on the improvement of the production system of buffalo meat. Further investigations on a larger number of animals studying the effects of on-farm handling, transport, and lairage phase on buffalo meat quality is warranted in order to improve the production of high quality buffalo meat.

\section{ACKNOWLEDGEMENTS}

This work was financially supported by the Agricultural Research Development Agency of the Ministry of Agriculture and Cooperatives, Royal Thai Government, Thailand.

\section{REFERENCES}

AOAC. 1995. Official methods of analysis. 15th edn. Association of Official Analytical Chemists, Arlington, Virginia.

AOAC. 2000. Official methods of analysis. 17th edn. Association of Analytical Chemists, Gaithersburg, Maryland.

Alfaia, C. M. M., V. S. S. Ribeiro, M. R. A. Lourenço, M. A. G. Quaresma, S. I .V. Martins, A. P . V. Portugal, C. M. G. A. Fontes, R. J. B. Bessa, M. L. F. Castro, and J. A. M. Prates. 2006. Fatty acid composition, conjugated linoleic acid isomers and cholesterol in beef from crossbred bullocks intensively produced from Alentejana purebred bullocks reared according to Carnalentejana-PDO specifications. Meat Sci. 72:425-436.

Anjaneyulu, A. S. R., S. S. Senger, V. Lakshmanan, and D. C. Joshi. 1985. Meat quality of male buffalo calves maintained on different levels of protein. Buffalo Bull. 4:45-47.

Bennet, L. L., A. C. Hammond, M. J. Williams, W. E. Kunkle, D. D. Johnson, R. L. Preston, and M. F. Miller. 1995. Performance, carcass yield, carcass quality characteristics of steers finished on rhizoma peanut-tropical grass pasture or concentrate. J. Anim. Sci. 73:1881-1887.

Boles, J. A., J. G. Bowman, L. M. M. Surber, and D. L. Boss. 2004. Effects of barley variety fed to steers on carcass characteristics and color of meat. J. Anim. Sci. 82:2087-2091.

Church, P. N. and J. M. Wood. 1991. The manual of manufacturing meat quality. Elsevier Science Publishers Ltd., Barking, UK.

Dannenberger, D., K. Nuernberg, G. Nuernberg, and K. Ender. 2006. Carcass- and meat quality of pasture vs. concentrate fed German Simmental German Holstein bulls. Arch. Tierz. 49:315-328.

Dannenberger, D., K. Nuernberg, G. Nuernberg, N. Scollan, H. Steinhart, and K. Ender. 2005. Effect of pasture vs. concentrate diet on CLA isomer distribution in different tissue lipids of beef cattle. Lipids 40:586-598.

Demirel, G., H. Ozpinar, B. Nazli, and O. Keser. 2006. Fatty acids of lamb meat from two breeds fed different forage: concentrate ratio. Meat Sci. 72:229-235.

Díaz, M. T., S. Velasco, V. Cañeque, S. Jauzurica, F. R. de Huidobro, C. Pérez, J. González, and C. Manzanares. 2002. Use of concentrate or pasture for fattening lambs and its effect on carcass and meat quality. Small Rumin. Res. 43:257-268.

Enser, M., K. G. Hallett, B. Hewett, G. A. J. Fursey, J. D. Wood, and G. Harrington. 1998. Fatty acid content composition of UK beef lamb muscle in relation to production system and implications for human nutrition. Meat Sci. 49:329-341.

FAO. 2000. Water buffalo: an asset undervalued. FAO Regional Office for Asia and the Pacific, Bangkok, Thailand.

FAO. 2001. Regional Asia and Pacific Publication 2001/17. FAO Regional Office for Asia and the Pacific, Bangkok, Thailand.

FAOSTAT. 2006. FAOSTAT Agriculture Data. Rome, Italy.

Ferrara, B. and F. Infascelli. 2004. Buffalo meat production: consumption, quality, carcass, sub products. In: Proceedings of the 4th World Buffalo Congress. Food and Agriculture Organization (FAO), Sao Paulo, Brazil. pp. 235-240.

Forrest, J. C., E. D. Aberle, H. B. Hedrick, M. D. Judge, and R. A. Merkel. 1975. Principles of meat science. W.H. Freeman, San Francisco, CA.

French, P., E. G. O’Riordan, F. J. Monahan, P. J. Caffrey, M. Vidal, M. T. Mooney, D. J. Troy, and A. P. Moloney. 2000. Meat quality of steers finished on autumn grass, grass silage or concentrate based diets. Meat Sci. 56:173-180.

French, P., E. G. O’Riordan, F. J. Monahan, P. J. Caffrey, M. T. Mooney, D. J. Troy, and A. P. Moloney. 2001. The eating quality of meat of steers fed grass and/or concentrates. Meat Sci. 57:379-386.

Folch, J., M. Lees, and G. H. S. Stanley. 1957. A simple method for the isolation purification of total lipids from animal tissues. J. Biol. Chem. 226:497-509.

Hess, H. D., L. M. Monsalve, C. E. Lascano, J. E. Carulla, T. E. Díaz, and M. Kreuzer. 2003. Supplementation of a tropical 
grass diet with forage legumes and Sapindus saponaria fruits: effects on in vitro ruminal nitrogen turnover and methaogenesis. Aust. J. Agric. Res. 54:703-713.

Hill, F. 1966. The solubility of intramuscular collagen in meat animals of various ages. J. Food Sci. 31:161-166.

Honikel, K. O. 1987. How to measure the water holding capacity of meat? Recommendation of stardized methods. In: Evaluation control of meat quality in pigs (Ed. P. V. Tarrant, G. Eikelenboom, and G. Monin). Martinus Nijhoff, Dordrecht, The Netherlands. pp. 129-142.

Huff-Lonergan, E. and S. M. Lonergan. 2005. Mechanism of water holding capacity of meat: the role of post-mortem biochemical structural changes. Meat Sci. 71:194-204.

Ingawale, M. V. and R. L. Dhoble. 2004. Buffalo reproduction in India: an overview. Buffalo Bull. 23:4-9.

Irurueta, M., A. Cadoppi, L. Langman, G. Grigioni, and F. Carduza. 2008. Effect of aging on the characteristics of meat from water buffalo grown in the Delta del Paraná region of Argentina. Meat Sci. 79:529-533.

Jaturasitha, S. 2007. Meat management. 3rd edn. Mingmuang Press, Chiang Mai, Thailand. $171 \mathrm{p}$.

Jaturasitha, S., R. Norkeaw, T. Vearasilp, M. Wicke, and M. Kreuzer. 2009. Carcass and meat quality of Thai native cattle fattened on Guinea grass (Panicum maxima) or Guinea grasslegume (Stylosanthes guianensis) pasture. Meat Sci. 81:155162.

Jung, D. H., H. G. Biggs, and W. R. Moorehead. 1975. Colorimetry of serum cholesterol with use of ferric acetate uranyl acetate and ferrous sulfate/sulfuric acid reagents. Clin. Chem. 21:1526-1530.

Kandeepan, G., S. Biswas, and R. S. Rajkumar. 2009. Buffalo as a potential food animal. Int. J. Livest. Prod. 1:1-5.

Kritchevsky, D. 2000. Antimutagenic and some other effects of conjugated linoleic acid. Br. J. Nutr. 83:459-465.

Lapitan, R. M., A. N. Del Barrio, O. Katsube, T. Ban-Tokuda, E. A. Orden, A. Y. Robles, L. C. Cruz, Y. Kana, and T. Fujihara. 2008. Comparison of fattening performance in Brahman grade cattle (Bos indicus) and crossbred water buffalo (Bubalus bubalis) fed on high roughage diet. Anim. Sci. J. 79:76-82.

Lawrie, R. A. 1998. Meat science. 6th edn. Pergamon Press, Oxford, UK. pp. 212-257.

Listrat, A., N. Rakadjiyski, C. Jurie, B. Picard, C. Touraille, and Y. Geay. 1999. Effect of the type of diet on muscle characteristics and meat palatability of growing Salers bulls. Meat Sci. 53:115-124.

Maltin, C. A., G. E. Lobley, C. M Grant, L. A. Miller, D. J: Kyle, G. W. Horgan, K. R. Mattews, and K. D. Sinclair. 2001. Factors influencing beef eating quality: 2. Effects of nutritional regimen and genotype on muscle fibre characteristics. Anim. Sci. 72:279-287.

Marino, R., M. Albenzio, A. Girolami, A. Muscio, A. Sevi, and A. Braghieri. 2006. Effect of forage to concentrate ratio on growth performance, and on carcass and meat quality of Podolian young bulls. Meat Sci. 72:415-424.

Miller, G. J., T. R. Varnell, and R. W. Rice. 1967. Fatty acid composition of certain ovine tissues as affected by maintenance level rations of roughage and concentrate. J. Anim. Sci. 29:41-45.
Mitchell, G. E., A. W. Reed, and S. A. Rogers. 1991. Influence of feeding regimen on the sensory qualities and fatty acid contents of beef steaks. J. Food Sci. 56:1102-1103.

Morrison, W. R. and L. M. Smith. 1964. Preparation of fatty acid methyl esters and dimethyl-acetals from lipids with boron fluoride-methanol. J. Lipid Res. 5:600-608.

Mortensen, M., H. J. Andersen, S. B. Engelsen, and H. C. Bertram. 2006. Effect of freezing, thawing and cooking rate on water distribution in two pork qualities. Meat Sci. 72:34-42.

Muir, P. D., J. M. Deaker, and M. D. Bown. 1998. Effects of forage- and grain-based feeding systems on beef quality: A review. NZ J. Agric. Res. 41:623-635.

Myers, S. E., D. B. Faulkner, T. G: Nash, L. L. Berger, D. F. Parrett, and F. K. McKeith. 1999. Performance and carcass traits of early-weaned steers receiving either a pasture growing period or a finishing diet at weaning. J. Anim. Sci. 77:311-322.

Nanda, A. S. and T. Nakao. 2003. Role of buffalo in the socioeconomic development of rural Asia: current status and future prospectus. Anim. Sci. J. 74:443-455.

Nuernberg, K., D. Dannenberger, G. Nuernberg, K. Ender, J. Voigt, N. D. Scollan, J. D. Wood, G. R. Nute, and R. I. Richardson. 2005. Effect of a grass-based and a concentrate feeding system on meat quality characteristics and fatty acid composition of longissimus muscle in different cattle breeds. Livest. Prod. Sci. 94:137-147.

Raes, K., A. Balcan, P. Dirinck, A. De Winne, E. Clayes, C. Demeyer, and S. De Smet. 2003. Meat quality, fatty acid composition and flavour analysis in Belgian retail beef. Meat Sci. 65:1237-1246.

Realini, C. E., S. K. Duckett, G. W. Brito, M. D. Rizza, and D. De Mattos. 2004. Effect of pasture vs. concentrate feeding with or without antioxidants on carcass characteristics, fatty acid composition, and quality of Uruguayan beef. Meat Sci. 66:567-577.

Rossell, J. B. 1994. Measurement of rancidity. In: Rancidity in Foods (Ed. J. C. Allen, and R. J. Hamilton). Blackie Academic and Professional, London, UK. pp. 22-53.

Sami, A. S., C. Augustini, and F. J: Schwarz. 2004. Effects of feeding intensity and time on feed on performance, carcass characteristics and meat quality of Simmental bulls. Meat Sci. 67:195-201.

Sami, A. S., J. Koegel, H. Eichinger, P. Freudenreich, and F. J. Schwarz. 2006. Effect of the dietary energy source on meat quality and eating quality attributes and fatty acid profile of Simmental bulls. Anim. Res. 55:287-299.

Sañudo, C., M. M. Campo, I. Sierra, G. A. María, J. L. Olleta, and P. Santolaria. 1997. Breed effect on carcass and meat quality of suckling lambs. Meat Sci. 46:357-365.

SAS Institute Inc. 2010. SAS/STAT User's guide: Version 9.2. SAS Institute Inc., Cary, North Carolina.

Serrano, E., P. Pradel, R. Jailler, H. Dubroeucq, D. Bauchart, J. F. Hocquette, A. Listrat, J. Agabriel, and D. Micol. 2007. Young Salers suckled bull production: effect of diet on performance, carcass and muscle characteristics and meat quality. Animal 7:1068-1079.

Scollan, N., H. F. Hocquette, K. Nuernberg, D. Dannenberger, I. Richardson, and A. Moloney. 2006. Innovations in beef production systems that enchance the nutritional and health value of beef lipids and their relationship with meat quality. 
Meat Sci. 74:17-33.

Spanghero, M., L. Gracco, R. Valusso, and E. Piasentier. 2004. In vivo performance, slaughtering traits and meat quality of bovine (Italian Simmental) and buffalo (Italian Mediterranean) bulls. Livest. Prod. Sci. 91:129-141.

Steen, R. W. J., N. P: Lavery, D. J. Kilpatrick, and M. G. Porter. 2003. Effects of pasture and high-concentrate diets on the performance of beef cattle, carcass composition at equal growth rates, and the fatty acid composition of beef. NZ J. Agric. Res. 46:69-81.

Tiwari, C. M., S. B. Jadhao, M. Chramoni, S. Anan, and M. Y. Khan. 2001. Studies on carcass characteristics and economics of supplementation of different protein to ammoniated strawbased rations in growing buffalo calves. Buffalo J. 2:179-193.

van Soest, P. J., J. B. Robertson, and B. A. Lewis. 1991. Methods of dietary fiber, neutral detergent fiber, and nonstarch polysaccharides in relation to animal nutrition. J. Dairy Sci. 74:3583-3597.

Varela, A., B. Oliete, T. Moreno, C. Portela, L. Monserrrat, J. A. Carballo, and L. Sánchez. 2004. Effect of pasture finishing on the meat characteristics and intramuscular fatty acid profile of steers of the Rubia Gallega breed. Meat Sci. 67:515-522.

Valenzuela, A. and N. Morgado. 1999. Trans fatty acid isomers in human health and in the food industry. Biol. Res. 32:273-287.

Varnam, A. H. and J. P. Sutherl. 1995. Meat and meat products: Technology, chemistry and microbiology. 1st edn. Chapman and Hall, London, UK.
Vestergaard, M., M. Therkildsen, P. Henckel, L. R. Jensen, H. R. Andersen, and K. Sejrsen. 2000. Influence of feeding intensity, grazing and finishing feeding on meat and eating quality of young bulls and the relationship between muscle fibre characteristics, fibre fragmentation and meat tenderness. Meat Sci. 54:187-195.

Wanapat, M., A. Ngarmasang, S. Kokhuntot, C. Wachirapakom, and P. Rowlinson. 2000. A comparative study on the ruminal microbial population of cattle and swamp buffalo raised under traditional village conditions in the northeast of Thailand. Asian-Aus. J. Anim. Sci. 13:918-921.

Wheeler, T. L., S. D. Shacklford, and M. Koohmaraie. 2002. Technical note: Sampling methodology for relating sarcomere length, collagen concentration, and the extent of postmortem proteolysis to beef and pork longissimus tenderness. J. Anim. Sci. 80:982-987.

Wood, J. D., M. Enser, A. V. Fisher, G. R. Nute, P. R. Sheard, R. I. Richardson, S. I. Hughes, and F. M. Whittington. 2008. Fat deposition, fatty acid composition and meat quality: A review. Meat Sci. 78:343-358.

Yang, A., M. C. Lanari, M. Brewster, and S. K. Tume. 2002. Lipid stability and meat colour of beef from pasture- and grain-fed cattle with or without vitamin E supplement. Meat Sci. 60:4150.

Ziauddin, K. S., S. Mahendraker, D. N. Rao, B. S. Ramesh, and B. L. Amla. 1994. Observations on some chemical and physical characteristics of buffalo meat. Meat Sci. 37:103-113. 